\title{
The Effects of Intramolecular Hydrogen Bonding on the Reactivity of Phenoxyl Radicals in Model Systems
}

\author{
Michael Lesslie, Andrii Piatkivskyi, John Lawler, Sandra Osburn, ${ }^{\dagger}$ Richard A. J. O’Hair, ${ }^{\dagger}$ and \\ Victor Ryzhov*
}

Department of Chemistry and Biochemistry, and Center for Biochemical and Biophysical Sciences, Northern Illinois University, DeKalb, IL 60115, USA

$\dagger$ ARC Centre of Excellence for Free Radical Chemistry and Biotechnology, School of Chemistry and Bio21 Institute of Molecular Science and Biotechnology, The University of Melbourne, 30 Flemington Road, Parkville, Victoria 3010, Australia.

*Corresponding author, Email: ryzhov@niu.edu

\begin{abstract}
:
The effects of hydrogen bonding on the gas-phase reactivity of phenoxyl oxygen radicals were investigated experimentally and theoretically in model systems and the dipeptide LysTyr. Gasphase ion-molecule reactions were carried out between radical cations of several aromatic nitrogen bases with the neutrals nitric oxide and $n$-propyl thiol. The variation in the structure of the model compounds allowed the four-, five-, and six-membered ring to be formed between the protonated nitrogen and the phenoxyl oxygen. The hydrogen bond length was calculated to decrease in the series (1-4), which coincided with the decrease in reaction rates towards both nitric oxide and $n$-propyl thiol. A control radical cation with no hydrogen-bonding capability displayed faster reactivity. DFT calculations found that the lowest energy structure of the distonic radical cation of the dipeptide $\left[\operatorname{Lys} \operatorname{Tyr}\left(\mathrm{O}^{\circ}\right)\right]^{+}$has a short hydrogen bond between the protonated Lys side chain and the phenoxyl oxygen, $1.70 \AA$, which is consistent with its low reactivity.
\end{abstract}

\section{Keywords:}


Radical ions, tyrosyl radicals, ion-molecule reactions, hydrogen bonding, density functional theory calculations 


\section{Introduction:}

Free radicals play key roles in protein chemistry due in part to their ability to transform substrates within the active sites of enzymes [1,2]. Radical sites in proteins are normally found on reactive amino acid side chains, of which, tyrosine phenoxyl radicals are among the most prominent (Scheme 1, A). These tyrosyl radicals are thought to be important intermediates in the action of the enzyme Class I Ribonucleotide Reductase (RNR) of E. Coli [3-5], production of oxygen in photosystem II [6-8], and the oxidation of peroxides in cytochrome C oxidases [9]. They have also been implicated in radical-induced protein damage, and are the precursors of various post-translational modifications (3,3'-dityrosine, 3-nitrotyrosine, and tyrosine-cytosine cross-linking) [10-13].

With the abundance of recent experimental data obtained via X-ray crystallography, high-frequency EPR, and ENDOR spectroscopy, which revealed structural information about local protein environments, it is widely accepted that tyrosyl radicals are often stabilized by hydrogen bonding [14-23]. Hydrogen bonding between a phenolic hydrogen and a properly oriented basic group such as histidine residue (Scheme 1, B [19]) modulates the formation and chemical behavior of the ensuing tyrosyl radical by changing redox potential of the tyrosine/tyrosyl radical pair [19, 24-29].

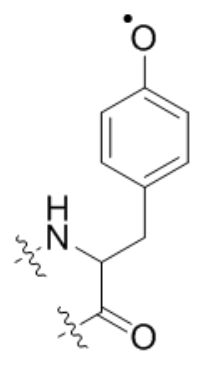

A

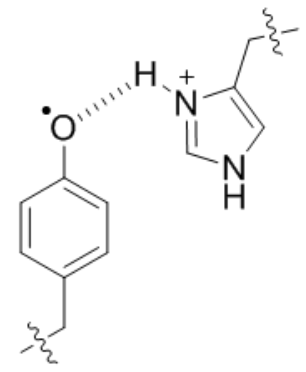

B

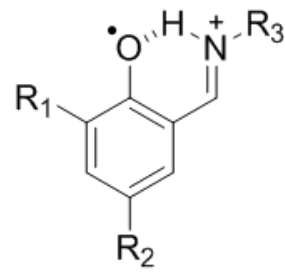

C

Scheme 1

There has been considerable interest in developing model systems to better understand the effects of hydrogen bonding on the properties of tyrosyl radicals [17, 30-33]. Most of these systems incorporate both a phenol and a basic nitrogen atom in a close proximity to facilitate the formation of hydrogen-bonded phenoxyl radical, as shown for $\mathbf{C}$ in Scheme 1 [31]. Varying the substituents in the phenyl ring and the chemical surroundings of the nitrogen was shown to affect both redox potentials and the EPR signals $[17,27,28,34,35]$. 
Despite the success of solution-based approaches, there are several advantages of using mass spectrometry-based approaches to examine the fundamental gas-phase chemistry of relevant distonic ion model systems [36]. Apart from significantly reducing the time and sample quantity required for these studies, they shut down the possibility of radical self-termination reactions due to the columbic repulsion of the charge sites. In addition, they reduce the overall complexity of the system by limiting the chemistry of intramolecular interactions and avoiding complications from intermolecular hydrogen bonding with solvent molecules. Notwithstanding the recent renaissance of mass spectrometry-based studies of amino acid and peptide radical ions, the effects of hydrogen bonding on radical reactivity have not been widely studied. A rare example ascribed the differences between the gas-phase reactivity of distonic radical cations of cysteine and homocysteine to hydrogen bonding effects arising from the difference in the distances between the N-terminal hydrogen atom and the sulfur radical (Scheme 2) [37].<smiles></smiles>

$\operatorname{Cys}\left(\mathrm{S}^{*}\right)$

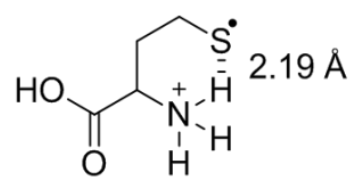

$\operatorname{Hcy}\left(\mathrm{S}^{*}\right)$

Scheme 2

Mass spectrometry has been used to study gas-phase chemistry of tyrosyl radicals [3840]. Siu and co-workers initially demonstrated the ability to form radical cations of peptides using the ternary copper (II) complex dissociation method in peptides containing tyrosine and an assisting basic amino acid [39]. This method was later utilized to form radicals and study a wide variety of tyrosine-containing peptides [40-43]. Covalent chemical modification of the tyrosine side chain and subsequent homolytic cleavage of a labile bond has been another productive route to formation of Tyr-based radical cations. This method has been successful in generating radical cations of iodotyrosine-containing peptides through photo-irradiation by Julian and co-workers $[44,45]$. They postulated that the initial phenyl carbon radical can quickly rearrange into the oxygen-based phenoxyl radical species $[45,46]$. However, because the tyrosyl radical easily loses its side chain in the gas phase, resulting in the captodatively-stabilized glycine radical, forming and studying the oxygen-based radical cation of tyrosine is a challenge [47-49]. Sui and co-workers were able to form small amounts of the tyrosyl radical through collision-induced dissociation (CID) of $\left[\mathrm{Cu}(\mathrm{Tyr})_{2}\right]^{2+}$ complex [47]. However, these ions dissociated rapidly to 
yield the p-hydroxybenzyl and p-cresol radical cations, which indicated the dissociation of the $\alpha$ $\beta$ bond and loss of the side chain [47]. Similarly, radical generation at tyrosine residues in peptides are known to result in characteristic side chain losses under mild CID conditions [48, 50].

In this study, we circumvent this problem by using model nitrogen bases 1-4 (Scheme 3) that possess a phenoxyl radical site but are stable with respect to Tyr side chain elimination. Choosing the position of the nitrogen atom in the molecule allows us to vary the extent of hydrogen bonding in the resulting radical cation. We utilize gas-phase ion-molecule reactions (IMRs) to probe the reactivity of these radical species and density functional theory (DFT) calculations to complement the experimental data. We also examine the chemistry of the radical cation of the dipeptide, $\left[\operatorname{Lys} \operatorname{Tyr}(\mathrm{O} \bullet]^{+}\right.$.
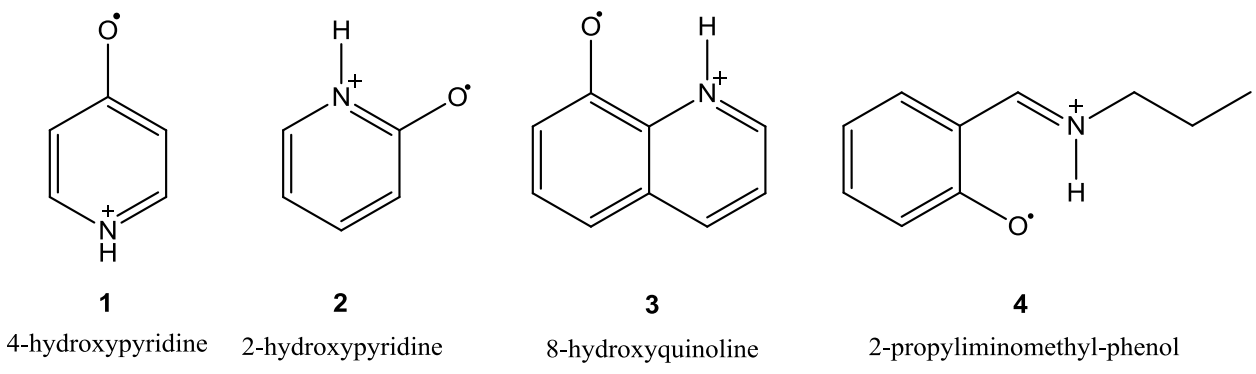

Scheme 3

\section{Experimental:}

Materials:

All chemicals and reagents were used as received without any further purification. All model compounds, including 8-hydroxyquinoline, 2-hydroxypyridine, 4-hydroxypyridine, 2methoxypyridine, and 2-propyliminomethyl-phenol, were purchased from Sigma-Aldrich (Milwaukee, WI). The dipeptide LysTyr was synthesized by, and purchased from Selleckchem (Houston, TX). The copper salt $\mathrm{CuSO}_{4}$ and the auxiliary ligand 2,2':6',2"'-terpyridine, were purchased from Sigma-Aldrich (Milwaukee, WI). Premixed gas containing 1\% nitric oxide in laser grade helium and well as pure nitric oxide were purchased from AirGas (Chicago, IL). The neutral reagent $n$-propyl thiol was purchased from Sigma Aldrich (Milwaukee, WI). Methanol was purchased from Fisher (Pittsburg, PA). Water was purified (18 M $\Omega$ ) in-house. 


\section{Mass Spectrometry:}

Mass spectrometry experiments were carried out using a Bruker Esquire 3000 quadrupole ion trap mass spectrometer (Bruker Daltonics, Bremen, Germany) modified to conduct ionmolecule reactions as described previously [51].

Stock solutions of the model compounds were prepared as $1 \mathrm{mM}$ in methanol. The production of the phenoxyl radicals on all species containing hydrogen bonds were achieved via the copper complex dissociation method, as previously described [38, 39]. The appropriate stock solution was mixed at a 1:1 ratio with a solution of $1 \mathrm{mM} \mathrm{CuSO}_{4}$ and $1 \mathrm{mM} \mathrm{2,2';6',2"-terpyridine}$ in 1:1 water/methanol and allowed to react for $30 \mathrm{~min}$. All reaction mixtures were diluted 100fold with methanol before injection.

All samples were subsequently introduced into the electrospray ionization (ESI) source of the mass spectrometer at a flow rate of $5 \mu \mathrm{L} \mathrm{min}^{-1}$. The nebulizer gas, needle voltage, and temperature were adjusted to approximately $12 \mathrm{PSI}, 4.0 \mathrm{kV}$, and $250{ }^{\circ} \mathrm{C}$. All other tunable instrument parameters were optimized to give maximum yield of the desired ions.

The formation of the radical ions of interest was achieved through successive isolation of the parent ion, CID, and a second isolation of the radical cation. The isolation window used in these experiments ranged from 0.7 to $2.0 \mathrm{~m} / \mathrm{z}$. The exact value was determined during the experiment as the width that resulted in the maximum abundance of the desired ion while excluding all other ions. The CID amplitude ranged from $0.40-0.75 \mathrm{~V}$ and was experimentally set to the value that yielded the greatest intensity of the desired fragment ion.

\section{Ion-Molecule Reactions:}

The isolated radical cations were subjected to IMRs with the neutral species nitric oxide and $n$-propyl thiol. Reactions were achieved by introducing nitric oxide into the trap via the helium line from a $1 \%$ nitric oxide in helium premixed cylinder. The internal helium regulator was unmodified from normal usage. The $n$-propyl thiol was introduced to the trap through a leak valve, as previously described [37]. In both cases, a scan delay was employed and determined the reaction time. The exponential decay of the reactant radical cation was found by monitoring the relative ion intensity over a series of delay times $(0-5000 \mathrm{~ms})$. Each time point was acquired for a minimum of $1 \mathrm{~min}$. The partial pressure of each of the neutral reactants was determined using the fastest reaction we have seen, that of 4-hydroxypyridine, which was assumed to occur 
at collision rate. Molecular polarizabilities of the model bases were calculated by the approach of Miller and Savchik [52]. Ion-molecules collisional rate constants were calculated using the Langevin equation and then dipole-corrected as described by $\mathrm{Su}$ and Chesnavich [53]. The partial pressure of nitric oxide was determined to be $\sim 1 \times 10^{-6}$ Torr and that of $n$-propyl thiol was $\sim 1 \times 10^{-7}$ Torr. Calibration of the partial pressure was done each day that an experiment was performed. These partial pressures were used for the determining the rate constants.

Verification of relative reactivity for slower reacting radical cations was achieved by reacting the isolated radical with nitric oxide introduced through a leak valve, which was able to supply a higher partial pressure of the gas. The reaction time was determined based on a scan delay of $1000 \mathrm{~ms}$ before the final product ion scan.

\section{Density Functional Theory Calculations:}

Optimization of the geometries for each of the structures was done using the Gaussian 09 suite of programs.[54] Initial optimizations were performed using the hybrid B3LYP functional and the $3-21 \mathrm{G}^{*}$ basis set. All minima located at this level of theory were then re-optimized using the same functional and the $6-311++\mathrm{G}(\mathrm{d}, \mathrm{p})$ basis set. Zero-point corrected energies were computed at the same level of theory. 


\section{Results and Discussion:}

The generation of the phenoxyl radical cations of all model hydrogen-bonded compounds was achieved via the dissociation of the copper ternary metal complex (Eq. 1) [38, 39].

$$
\left[\mathrm{Cu}^{\mathrm{II}}(\text { terpy })(\mathrm{M})\right]^{2+} \rightarrow\left[\mathrm{Cu}^{\mathrm{I}}(\text { terpy })\right]^{+}+[\mathrm{M}]^{\cdot+}
$$

For all the systems investigated, CID produced primarily the radical of interest and the reduced copper and terpyridine complex, $\left[\mathrm{Cu}^{\mathrm{I}}(\mathrm{L})\right]^{+}$. Minor amounts of proton transfer, resulting in $\left[\mathrm{Cu}^{\mathrm{II}}(\mathrm{M}-\mathrm{H})\right]^{+}$, were also seen during complex CID (Fig. 1a). The high yield of the radical cation and the minimal amount of competing fragmentation channels allowed for ample ion intensity to carry out IMRs and determine rate constants.

\section{[Insert Figure 1]}

The 4-hydroxypyridine radical cation (1), which lacks the ability to form an $\mathrm{O}^{\circ} \ldots \mathrm{H}-\mathrm{N}$ hydrogen bond, was generated via homolytic cleavage of a methyl group (loss of $15 \mathrm{Da}$ ) from the 4-methoxypyridine precursor ion (Eq. 2 and Fig. S1).

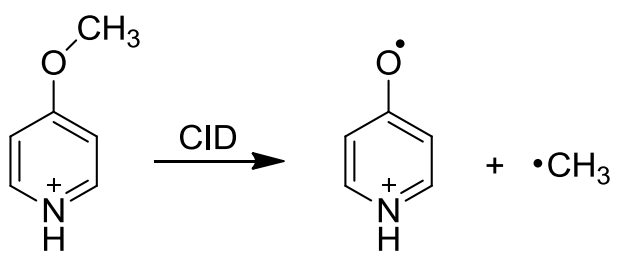

This method was chosen as it specifies the initial location of the radical on the oxygen atom. In the hydrogen-bonded compounds, formed through copper complex dissociation (Eq. 1), the initial radical location is unknown. However, due to the proximity of the oxygen and nitrogen atoms, and the bridging hydrogen, conversion to the ground-state oxygen-based radical structure is able to occur from the canonical radical cation should that species be formed initially (Eq. 3).<smiles>Oc1cccc2ccccc12</smiles>

DFT calculations for the radical cations used in our study found that the structure with the nitrogen protonated and the radical located on the phenoxyl oxygen is the lowest-energy isomer for compounds 1-3 and the only stable isomer for compound 4 (Table S1). A compound similar to the radical cation of model 4 (Scheme $1 \mathrm{C} ; \mathrm{R}_{1}, \mathrm{R}_{2}=\mathrm{H}, \mathrm{R}_{3}=\mathrm{C}_{3} \mathrm{H}_{7}$ ) was studied previously in solution [31], and was assigned the same structure which gives further confirmation to our approach. 
The lack of any hydrogen bonding in the 4-hydroxypyryidine radical cation (1) allows for this compound to be used as a control. The remaining radical cations, 2-hydroxyquinoline (2), 8hydroxyquinoline (3), and 2-propyliminomethylphenol (4), have 4-, 5-, and 6-membered hydrogen-bonding ring structures, respectively. To further evaluate the compounds, DFT calculations were used to determine the hydrogen bond length in the ground state structures (Figure 2). As expected, hydrogen bond lengths decreased as the number of ring members increased, ranging from $\sim 2.5 \AA$ for 2-hydroxypyridine (2), to $\sim 2.3 \AA$ for 8-hydroxyquinoline (3), and $\sim 1.9 \AA$ for 2-propyliminomethylphenol (4).

[Insert Figure 2]

Previous studies in solution by Ingold and co-workers have evaluated the reactivity of phenols with various reactive radical species and found that the degree of intermolecular hydrogen bonding of the phenol to the solvent generally decreases the reaction rate [55-57]. All of these studies investigated radicals reacting with hydrogen-bonded compounds. For the instances where intramolecular hydrogen bonding within the radical-containing species affects its reactivity, there is very little data. Our previous study explained the differences between the gasphase reactivity of distonic radical cations of cysteine and homocysteine by the difference in the distances between the N-terminal hydrogen atom and the sulfur radical (Scheme 2) [37]. Sulfur, however, is not as efficient at forming strong hydrogen bonds as $\mathrm{F}, \mathrm{O}$, and $\mathrm{N}$.

This study aims to evaluate the effect of intramolecular $\mathrm{O}^{\circ} \ldots \mathrm{H}-\mathrm{N}$ hydrogen bonding on oxygen radical reactivity in the gas phase. To address this question, model compounds 1-4 were reacted with nitric oxide yielding radical combination, which results in an addition of 30 Da to the radical cation (eq. 4 and Fig. 1b):

$$
\mathrm{M}^{\cdot+}+{ }^{\cdot} \mathrm{NO} \rightarrow[\mathrm{M}+\mathrm{NO}]^{+}
$$

This was the only reaction product observed in all cases. This data was compiled with the calculated hydrogen bond lengths (Table 1). The reactivity of 4-hydroxypyridine (1) was the highest we have seen and was set to the collision rate as determined by the dipole-corrected Langevin equation. As shown in the table, the rate constants decrease substantially with increasing hydrogen bonding.

[Insert Table 1]

For the slowest reacting compound, 2-propyliminomethyl-phenol (4), the partial pressure of the stock $1 \%$ nitric oxide in helium was not sufficient to bring the reaction rate into the 
quantifiable range. To circumvent this issue, the partial pressure in the trap was increased with additional nitric oxide via a leak valve [37]. This allowed for the determination of the upper limit of the rate constant. At this higher pressure of nitric oxide, compounds $\mathbf{1}$ and $\mathbf{2}$ were completely reacted after $1 \mathrm{~s}$, while compounds $\mathbf{3}$ and $\mathbf{4}$ had product ion intensities of $\sim 3 \%$ and $\sim 1 \%$, respectively, relative to the intensity of the initial radical cation. As expected, there was an evident decrease in reactivity with decreasing hydrogen bond length. In the case of the 2hydroxypyridine radical cation (2) the hydrogen bond length is $2.45 \AA$ and the geometry of the ion is unfavorable because $\mathrm{N}-\mathrm{H}$ and $\mathrm{C}-\mathrm{O}$ bonds point away from one another. The 8hydroxyquinoline radical cation (3) has a shorter hydrogen bond of $2.26 \AA$ with a 5-membered ring structure resulting in more favorable hydrogen bonding angle. This correlates with a factor of six decrease in rate constants going from 2 to 3 . The slowest reacting compound, 2propyliminomethyl-phenol (4), had the shortest hydrogen bond of $1.87 \AA$ which is part of a sixmembered ring enabling almost optimal orbital interaction for hydrogen bonding. The corresponding decrease in reaction rate constants from $\mathbf{3}$ to $\mathbf{4}$ is at least a factor of five.

In addition, we computationally explored the thermodynamics of the radical ion recombination reaction with ${ }^{\circ} \mathrm{NO}$ (eq. 4). The calculated enthalpies of reaction (4) for the radical cation species $\mathbf{1}$ - $\mathbf{4}$ are given in Table 1. The corresponding reaction free energies as well as the product geometries are shown in Figure S2. The recombination reaction for the "control" radical cation 1 was calculated to be exothermic by $164 \mathrm{~kJ} \mathrm{~mol}^{-1}$. For the 2-hydroxypyridine radical cation (2), $\Delta \mathrm{H}$ was found to be $-103 \mathrm{~kJ} \mathrm{~mol}^{-1}$, while for the 8-hydroxyquinoline radical cation (3), the corresponding enthalpy change was - $64 \mathrm{~kJ} \mathrm{~mol}^{-1}$. The radical cation of 2propyliminomethyl-phenol (4) had the lowest enthalpy change at - $61 \mathrm{~kJ} \mathrm{~mol}^{-1}$. A typical O-NO bond dissociation energy (BDE) is the range of 45-75 $\mathrm{kJ} \mathrm{mol}^{-1}$ in substituted phenols [58], where electron-withdrawing substituents stabilize the radical less resulting in higher BDE values. In compound 4 the protonated imino substituent is highly electron-withdrawing. However, the BDE value falls in the middle of the typical O-NO range, possibly due to extra stabilization of the phenoxyl radical by the short hydrogen bond. These calculations suggest that both the exothermicity of reaction (4) and the length of hydrogen bonding correlate with the gas-phase reactivity towards NO in the series $\mathbf{1}-\mathbf{4}$. 
To further investigate the reactivity trends, the radical cations 1-4 were also subjected to reactions with $n$-propyl thiol. Such reactions proceeded to give hydrogen atom transfer (HAT) (Eq. 5 and Fig. 1c).

$$
\mathrm{M}^{\bullet+}+\mathrm{HS} \smile \longrightarrow[\mathrm{M}+\mathrm{H}]^{+}+\cdot \mathrm{S} \longrightarrow
$$

The neutral $n$-propyl thiol was introduced through a leak valve, and rate constants were determined (Table 1). As with the nitric oxide kinetic experiments, the fast reaction the 4hydroxypyridine radical cation was assumed to occur at collision rate. The decrease in reactivity of $n$-propyl thiol with compounds $2 \rightarrow 3 \rightarrow 4$ correlates with the relative length and geometry of the $\mathrm{O}^{\bullet}$....H-N hydrogen bond.

The degree of hydrogen bonding to the phenoxyl radical of tyrosine oxidation sites in proteins varies greatly across enzymes [59]. Even within RNRs, the mouse variety possesses a hydrogen bond to the radical, while the E. Coli version does not [60]. The redox-active phenol in E. Coli class I RNR does possess a hydrogen bond to a neighboring aspartate residue, but is rotated away and breaks hydrogen bond when oxidation occurs [60]. It has been proposed that state-specific changes in the hydrogen bonding to redox-active tyrosines, like those in E. Coli, may be an example of broader kinetic modulation of radical chemistry [61]. Therefore, the effect of hydrogen bonding on the reactivity of phenoxyl radicals is important to understanding oxidation mechanisms in enzyme catalysis.

While efforts to form the tyrosyl radical through dissociation of copper ternary complexes has not often been successful in generating suitable yields of the radical [47], formation of the tyrosine-based phenoxyl radical in peptides with neighboring basic amino acid residues has shown positive results $[39,40]$. To compare the results of the model compounds, the radical cation of the dipeptide LysTyr was generated. This type of radical was previously assigned the structure with protonated Lys side chain and the Tyr phenoxyl radical [39, 40]. The DFT analysis of gas-phase structures of [LysTyr $\left.\left(\mathrm{O}^{\circ}\right)\right]^{+}$revealed that the lowest-energy structure has a short hydrogen bond $(1.7 \AA$ ) from the N-terminal amine to the phenoxylic oxygen (Figure 3). This shows an example of the utility of the hydrogen bonding models, as with a shorter hydrogen bond than 2-propyliminomethyl-phenol (4), no substantial reactivity is expected from the gas-phase dipeptide radical cation. The reaction rate constants were found to be $<2 \times 10^{-12}$ $\mathrm{cm}^{3}$ molecules $\mathrm{s}^{-1}$ and $<3 \times 10^{-11} \mathrm{~cm}^{3}$ molecules ${ }^{-1} \mathrm{~s}^{-1}$ for reactions with nitric oxide and $n$-propyl thiol, respectively. In gas-phase peptide ions trapped at nearly thermal conditions, however, a 
mixture of the low-energy conformers is anticipated. Some contribution of the conformers lacking a hydrogen bond to the phenoxyl oxygen radical (See Figure S3) or isomeric radical cation structures could explain the reactivity.

[Insert Figure 3] 


\section{Conclusions:}

The gas-phase reactivity of radical cations containing a protonated nitrogen at various distances from the phenoxylic oxygen has been compared. There is a strong correlation between the intramolecular hydrogen bonding ability within the $\mathrm{N}-\mathrm{H} . .{ }^{\circ} \mathrm{O}$ motif and the rate of ionmolecule reactions of these radical species with nitric oxide and $n$-propyl thiol. The reactivity decreases going from the "control" radical ion 1 with no hydrogen-bonding capability to the 4-, 5-, and 6-membered ring structures 2 - 4 where the hydrogen bond progressively shortens. This trend follows the thermodynamics of the reaction (4) which becomes progressively less exothermic as the length of hydrogen bond decreases. There have been multiple studies of the effect of solvent-substrate hydrogen bonding on radical reactivity and the effects of intramolecular hydrogen bonding on the radical electrochemical production or EPR signature. However, this is one of a few works where the radical reactivity is directly affected by intramolecular hydrogen bond to the radical site.

The reactivity data presented herein provide a perspective into the properties of tyrosine phenoxyl radicals in proteins where they are often hydrogen-bonded. Our study confirms a possibility that the radical reactivity can be modulated via changing the hydrogen bond parameters within the radical microenvironment.

One of the main advantages of gas-phase studies is the ability to screen multiple compounds in a quick and efficient way with minimal reagent consumption. With that in mind, it is possible to investigate the effects of various substituents in compound $\mathbf{4}$ (as in Scheme 1C) on the radical reactivity. This will be a subject of future studies. 


\section{Acknowledgements:}

This work was supported by the Department of Chemistry and Biochemistry, Northern Illinois University. RAJO thanks the ARC CoE for support. 


\section{List of figures:}

Figure 1. a) CID of the doubly charged ternary copper complex $(\mathrm{m} / \mathrm{z}, 195.5)$, with 4hydroxypyridine as the model compound (M). Dissociation generates the radical cation of 4hydroxypyridine, $[\mathrm{M}]^{{ }^{+}}$, at $\mathrm{m} / \mathrm{z}, 95$ and the reduced copper complex, $\left[\mathrm{Cu}^{\mathrm{I}} \text { (terpy) }\right]^{+}$, at $\mathrm{m} / \mathrm{z} 296$. b) IMR of the 4-hydroxypyridine radical cation, $[\mathrm{M}]^{++}$, with nitric oxide. This reaction produced the radical combination product, $[\mathrm{M}+\mathrm{NO}]^{+}$, at $\mathrm{m} / \mathrm{z} 125$. Reaction time $75 \mathrm{~ms}$, NO pressure is ca. $1 \times 10^{-6}$ torr.

c) IMR of the 4-hydroxypyridine radical cation, $[\mathrm{M}]^{\cdot+}$, with $n$-propyl thiol. This reaction results in HAT, yielding $[\mathrm{M}+\mathrm{H}]^{+}$at $\mathrm{m} / z$. 96. Reaction time $250 \mathrm{~ms}$.

Figure 2. DFT-calculated (B3LYP 6-311++G(d,p)) lowest energy structures of model compounds for hydrogen bonding examination: 4-hydroxyquinoline (1), 2-hydroxyquinoline (2), 8-hydroxyquinoline (3), and 2-propyliminomehtylphenol (4). Hydrogen bond lengths (in $\AA$ ) are indicated in red.

Figure 3. Structure of the $\left[\operatorname{Lys} \operatorname{Tyr}\left(\mathrm{O}^{\circ}\right)\right]^{+}$radical cation in the gas phase calculated at the B3LYP $6-311++G(d, p)$ level of theory. The structure represents the lowest energy conformer with a hydrogen bond from the Lys side chain amine to the phenoxyl radical of $1.7 \AA$. 
a)

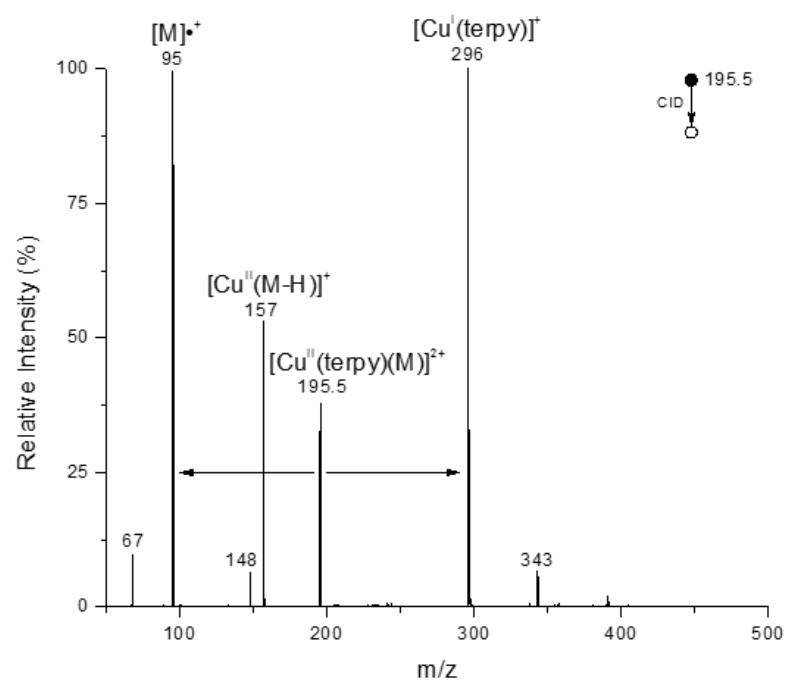

b)

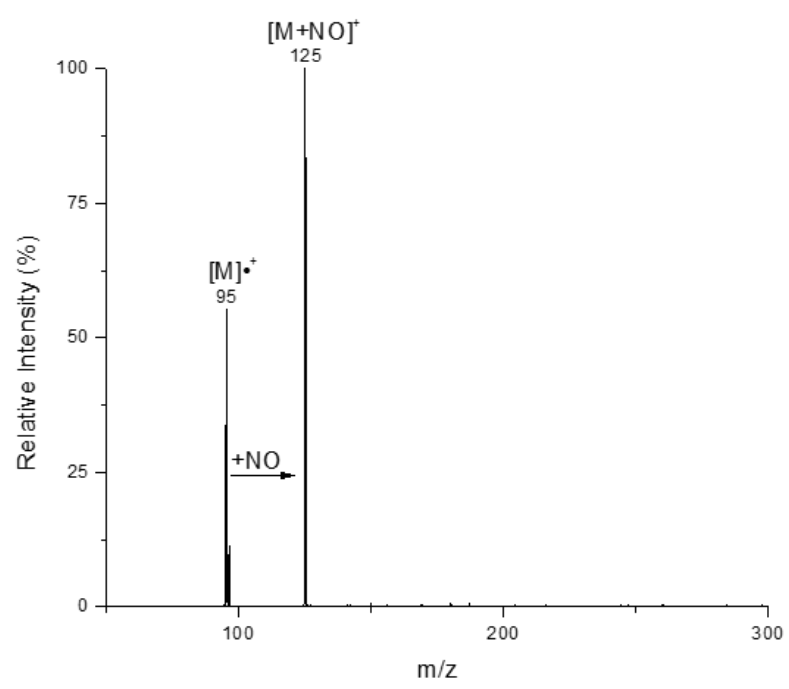

c)

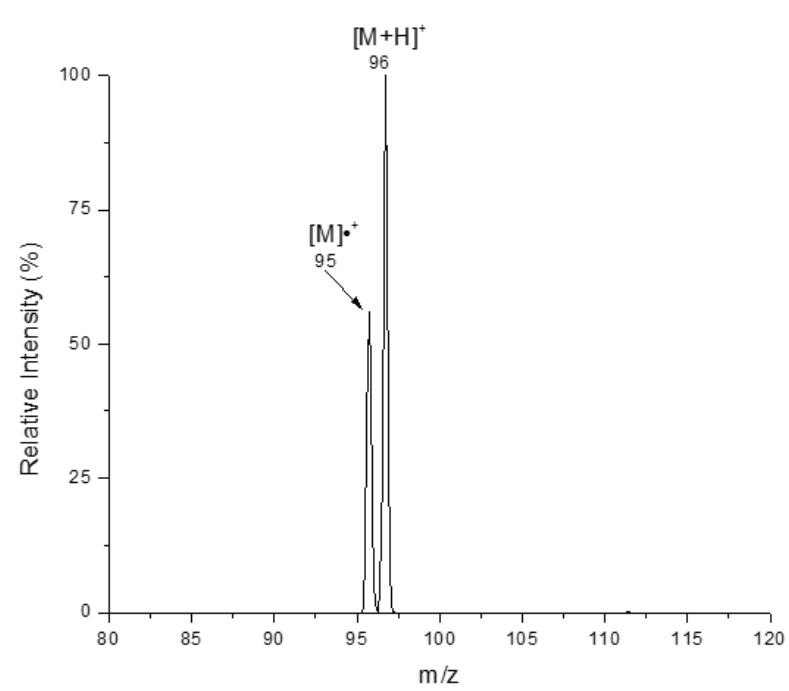

Figure 1 


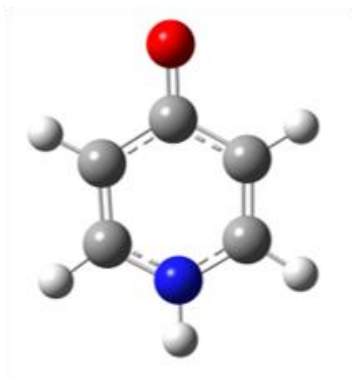

1

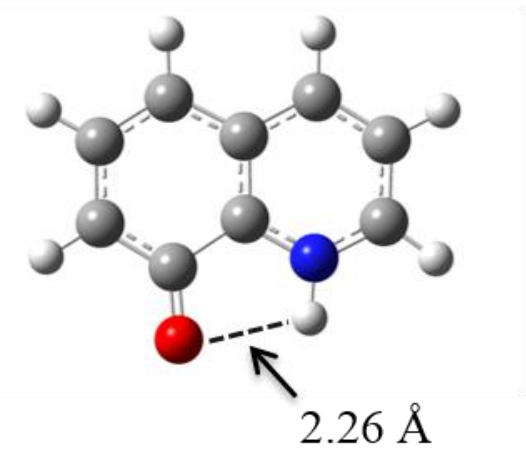

3
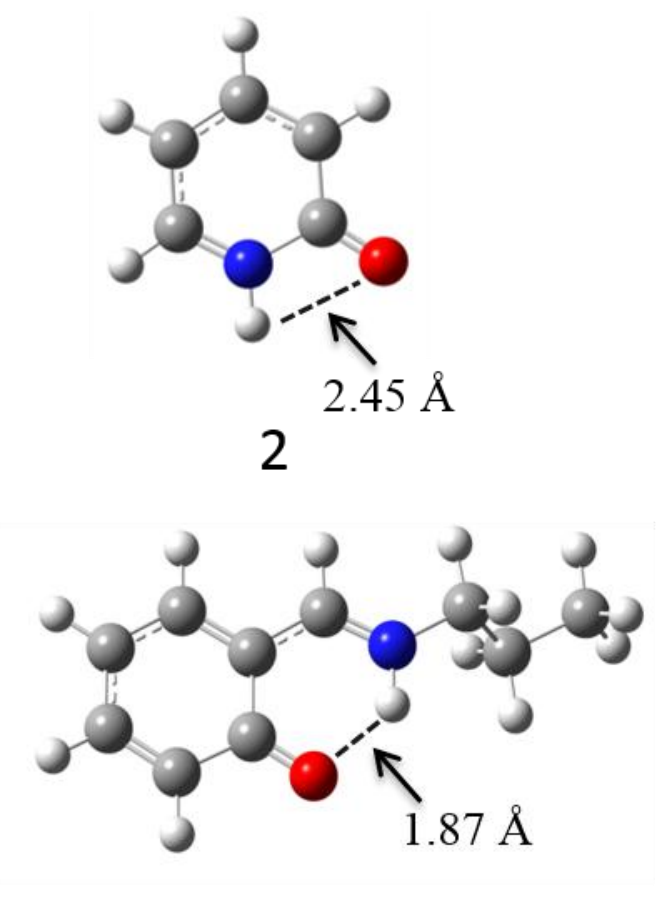

4

Figure 2 


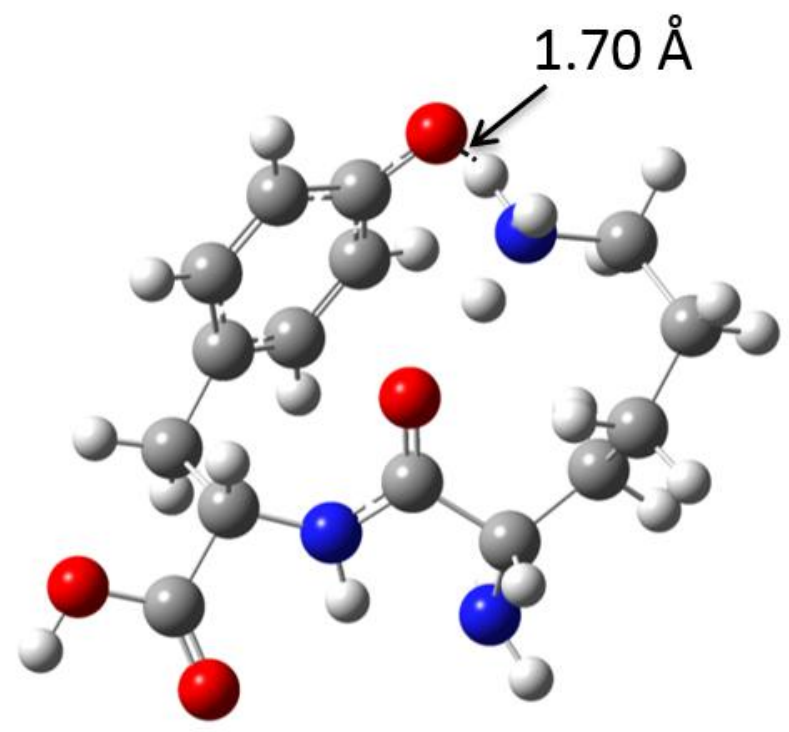

Figure 3 


\section{List of Tables:}

Table 1. Kinetics and thermodynamics for the reactions of model compounds 1-4 with nitric oxide and $n$-propyl thiol. 


\begin{tabular}{|c|c|c|c|c|c|c|}
\hline $\begin{array}{l}\text { Radical Cation } \\
\text { Species }\end{array}$ & $\begin{array}{l}\text { H-Bond } \\
\text { Length } \\
(\AA)^{\dagger}\end{array}$ & $\begin{array}{c}\text { Nitric Oxide } \\
\text { Rate Const. } \\
\left(\mathrm{cm}^{3} \text { molecules }^{-1} \mathrm{~s}^{-1}\right)\end{array}$ & $\begin{array}{l}\text { Nitric Oxide } \\
\% \text { of Col. Rate }\end{array}$ & $\begin{array}{c}\text { Nitric Oxide } \\
\Delta \mathrm{H} \\
(\mathrm{kJ} \text { mol-1 })^{\dagger}\end{array}$ & $\begin{array}{c}n \text {-propyl thiol } \\
\text { Rate Const. } \\
\left(\mathrm{cm}^{3} \text { molecules }^{-1} \mathrm{~s}^{-1}\right)\end{array}$ & $\begin{array}{l}n \text {-propyl thiol } \\
\% \text { of Col. Rate }\end{array}$ \\
\hline $\begin{array}{c}1 \\
\text { 4-Hydroxypyridine }\end{array}$ & -- & $6.6 \times 10^{-10}$ & 100 & -163.5 & $1.1 \times 10^{-9}$ & 100 \\
\hline$\frac{2}{2-H y d r o x y p y r i d i n e}$ & 2.45 & $3.3 \times 10^{-11}$ & 5.0 & -102.7 & $1.0 \times 10^{-10}$ & 91 \\
\hline $\begin{array}{c}\mathbf{3} \\
\text { 8-Hydroxyquinoline }\end{array}$ & 2.26 & $5 \times 10^{-12}$ & 0.7 & -64.4 & $1 \times 10^{-10}$ & 9 \\
\hline $\begin{array}{l}\mathbf{4} \\
\text { 2-Propyliminomethyl- } \\
\text { phenol }\end{array}$ & 1.87 & $<2 \times 10^{-12 \ddagger}$ & $<0.3^{*}$ & -61.4 & $<3 \times 10^{-11}$ & $<3^{*}$ \\
\hline
\end{tabular}

Calculated at the B3LYP 6-311++G(d,p) level of theory.

${ }^{\ddagger}$ Reactivity observed, but product yield was below quantifiable range. 


\section{References:}

[1] J. Stubbe, W.A. van der Donk, Protein radicals in enzyme catalysis, Chem. Rev. , 98 (1998) 705-762.

[2] M.J. Davies, R.T. Dean, Radical-mediated protein oxidation: from chemistry to medicine, Oxford University Press, 1997.

[3] J. Stubbe, P. Riggs-Gelasco, Harnessing free radicals: formation and function of the tyrosyl radical in ribonucleotide reductase, Trends Biochem. Sci., 23 (1998) 438-443.

[4] J. Stubbe, D.G. Nocera, C.S. Yee, M.C. Chang, Radical initiation in the class I ribonucleotide reductase: long-range proton-coupled electron transfer?, Chem. Rev. , 103 (2003) 2167-2202. [5] E.C. Minnihan, D.G. Nocera, J. Stubbe, Reversible, long-range radical transfer in E. coli class Ia ribonucleotide reductase, Acc. Chem. Res., 46 (2013) 2524-2535.

[6] D.A. Proshlyakov, M.A. Pressler, C. DeMaso, J.F. Leykam, D.L. DeWitt, G.T. Babcock, Oxygen activation and reduction in respiration: involvement of redox-active tyrosine 244, Science, 290 (2000) 1588-1591.

[7] C. Tommos, G.T. Babcock, Oxygen production in nature: a light-driven metalloradical enzyme process, Acc. Chem. Res., 31 (1998) 18-25.

[8] G.W. Brudvig, Water oxidation chemistry of photosystem II, Philos. Trans. R. Soc., B, 363 (2008) 1211-1219.

[9] F. MacMillan, A. Kannt, J. Behr, T. Prisner, H. Michel, Direct evidence for a tyrosine radical in the reaction of cytochrome c oxidase with hydrogen peroxide, Biochemistry, 38 (1999) 91799184.

[10] J.W. Heinecke, W. Li, G.A. Francis, J.A. Goldstein, Tyrosyl radical generated by myeloperoxidase catalyzes the oxidative cross-linking of proteins, J. Clin. Invest., 91 (1993) 2866.

[11] M.R. Gunther, L.C. Hsi, J.F. Curtis, J.K. Gierse, L.J. Marnett, T.E. Eling, R.P. Mason, Nitric oxide trapping of the tyrosyl radical of prostaglandin $\mathrm{H}$ synthase-2 leads to tyrosine iminoxyl radical and nitrotyrosine formation, J. Biol. Chem., 272 (1997) 17086-17090. [12] C. Giulivi, N. Traaseth, K. Davies, Tyrosine oxidation products: analysis and biological relevance, Amino acids, 25 (2003) 227-232.

[13] F. Ban, M.J. Lundqvist, R.J. Boyd, L.A. Eriksson, Theoretical studies of the cross-linking mechanisms between cytosine and tyrosine, J. Am. Chem. Soc., 124 (2002) 2753-2761. 
[14] C.T. Farrar, G.J. Gerfen, R.G. Griffin, D.A. Force, R.D. Britt, Electronic structure of the YD tyrosyl radical in photosystem II: A high-frequency electron paramagnetic resonance spectroscopic and density functional theoretical study, J. Phys. Chem. B, 101 (1997) 6634-6641. [15] P.J. van Dam, J.-P. Willems, P.P. Schmidt, S. Pötsch, A.-L. Barra, W.R. Hagen, B.M. Hoffman, K.K. Andersson, A. Gräslund, High-frequency EPR and pulsed Q-Band ENDOR studies on the origin of the hydrogen bond in tyrosyl radicals of ribonucleotide reductase R2 proteins from mouse and herpes simplex virus type 1, J. Am. Chem. Soc., 120 (1998) 5080-5085. [16] M. Engström, F. Himo, A. Gräslund, B. Minaev, O. Vahtras, H. Agren, Hydrogen bonding to tyrosyl radical analyzed by ab initio g-tensor calculations, J. Phys. Chem. A, 104 (2000) 51495153.

[17] M. Lucarini, V. Mugnaini, G.F. Pedulli, M. Guerra, Hydrogen-bonding effects on the properties of phenoxyl radicals. An EPR, kinetic, and computational study, J. Am. Chem. Soc., 125 (2003) 8318-8329.

[18] P.E. Siegbahn, Theoretical models for the oxygen radical mechanism of water oxidation and of the water oxidizing complex of photosystem II, Inorg. Chem. , 39 (2000) 2923-2935. [19] T. Maki, Y. Araki, Y. Ishida, O. Onomura, Y. Matsumura, Construction of persistent phenoxyl radical with intramolecular hydrogen bonding, J. Am. Chem. Soc., 123 (2001) 33713372.

[20] W.C. Voegtli, J. Ge, D.L. Perlstein, J.A. Stubbe, A.C. Rosenzweig, Structure of the yeast ribonucleotide reductase Y2Y4 heterodimer, Proc. Natl. Acad. Sci. U. S. A., 98 (2001) 1007310078.

[21] M. Uppsten, J. Davis, H. Rubin, U. Uhlin, Crystal structure of the biologically active form of class Ib ribonucleotide reductase small subunit from Mycobacterium tuberculosis, FEBS Lett., 569 (2004) 117-122.

[22] A. Liu, A.-L. Barra, H. Rubin, G. Lu, A. Gräslund, Heterogeneity of the local electrostatic environment of the tyrosyl radical in Mycobacterium tuberculosis ribonucleotide reductase observed by high-field electron paramagnetic resonance, J. Am. Chem. Soc., 122 (2000) 19741978.

[23] A. Ivancich, T.A. Mattioli, S. Un, Effect of protein microenvironment on tyrosyl radicals. A high-field (285 GHz) EPR, resonance Raman, and hybrid density functional study, J. Am. Chem. Soc., 121 (1999) 5743-5753. 
[24] U. Uhlin, H. Eklund, Structure of ribonucleotide reductase protein R1, Nature, 370 (1994) 533-539.

[25] M. Sjödin, S. Styring, H. Wolpher, Y. Xu, L. Sun, L. Hammarström, Switching the redox mechanism: models for proton-coupled electron transfer from tyrosine and tryptophan, J. Am. Chem. Soc., 127 (2005) 3855-3863.

[26] T. Irebo, S.Y. Reece, M. Sjödin, D.G. Nocera, L. Hammarström, Proton-coupled electron transfer of tyrosine oxidation: Buffer dependence and parallel mechanisms, J. Am. Chem. Soc., 129 (2007) 15462-15464.

[27] M.S. Caffrey, F. Daldal, H.M. Holden, M.A. Cusanovich, Importance of a conserved hydrogen-bonding network in cytochromes c to their redox potentials and stabilities, Biochemistry, 30 (1991) 4119-4125.

[28] F. Thomas, O. Jarjayes, H. Jamet, S. Hamman, E. Saint-Aman, C. Duboc, J.L. Pierre, How Single and Bifurcated Hydrogen Bonds Influence Proton-Migration Rate Constants, Redox, and Electronic Properties of Phenoxyl Radicals, Angew. Chem., Int. Ed., 43 (2004) 594-597.

[29] M. Foti, K. Ingold, J. Lusztyk, The surprisingly high reactivity of phenoxyl radicals, J. Am. Chem. Soc., 116 (1994) 9440-9447.

[30] G.F. Moore, M. Hambourger, M. Gervaldo, O.G. Poluektov, T. Rajh, D. Gust, T.A. Moore, A.L. Moore, A bioinspired construct that mimics the proton coupled electron transfer between P680•+ and the TyrZ-His190 pair of photosystem II, J. Am. Chem. Soc., 130 (2008) 1046610467.

[31] F. Thomas, O. Jarjayes, C. Duboc, C. Philouze, E. Saint-Aman, J.-L. Pierre, Intramolecularly hydrogen-bonded versus copper(ii) coordinated mono- and bis-phenoxyl radicals, Dalton Trans., (2004) 2662-2669.

[32] T. Brinck, M. Haeberlein, M. Jonsson, A computational analysis of substituent effects on the $\mathrm{OH}$ bond dissociation energy in phenols: polar versus radical effects, J. Am. Chem. Soc., 119 (1997) 4239-4244.

[33] R. Wanke, L. Benisvy, M.L. Kuznetsov, M.F.C. Guedes da Silva, A.J. Pombeiro, Persistent Hydrogen-Bonded and Non-Hydrogen-Bonded Phenoxyl Radicals, Chem. - Eur. J., 17 (2011) 11882-11892. 
[34] M. Lucarini, P. Pedrielli, G.F. Pedulli, S. Cabiddu, C. Fattuoni, Bond dissociation energies of $\mathrm{OH}$ bonds in substituted phenols from equilibration studies, J. Org. Chem., 61 (1996) 92599263.

[35] D. Wayner, E. Lusztyk, K. Ingold, P. Mulder, Application of Photoacoustic Calorimetry to the Measurement of the $\mathrm{OH}$ Bond Strength in Vitamin E ( $\alpha$-and $\delta$-Tocopherol) and Related Phenolic Antioxidants1, J. Org. Chem., 61 (1996) 6430-6433.

[36] K.M. Stirk, L.M. Kiminkinen, H.I. Kenttamaa, Ion-molecule reactions of distonic radical cations, Chem. Rev. , 92 (1992) 1649-1665.

[37] S. Osburn, T. Burgie, G. Berden, J. Oomens, R.A. O’Hair, V. Ryzhov, Structure and reactivity of homocysteine radical cation in the gas phase studied by ion-molecule reactions and infrared multiple photon dissociation, J. Phys. Chem. A, 117 (2012) 1144-1150.

[38] E. Bagheri-Majdi, Y. Ke, G. Orlova, I.K. Chu, A.C. Hopkinson, K.M. Siu, Copper-mediated peptide radical ions in the gas phase, J. Phys. Chem. B, 108 (2004) 11170-11181.

[39] I.K. Chu, C.F. Rodriquez, T.-C. Lau, A.C. Hopkinson, K.M. Siu, Molecular radical cations of oligopeptides, J. Phys. Chem. B, 104 (2000) 3393-3397.

[40] I.K. Chu, C.F. Rodriguez, A.C. Hopkinson, K.M. Siu, T.-C. Lau, Formation of molecular radical cations of enkephalin derivatives via collision-induced dissociation of electrospraygenerated copper (II) complex ions of amines and peptides, J. Am. Soc. Mass Spectrom., 12 (2001) 1114-1119.

[41] C.K. Barlow, W.D. McFadyen, R.A. O'Hair, Formation of cationic peptide radicals by gasphase redox reactions with trivalent chromium, manganese, iron, and cobalt complexes, J. Am. Chem. Soc., 127 (2005) 6109-6115.

[42] C.K. Barlow, D. Moran, L. Radom, W.D. McFadyen, R.A. O'Hair, Metal-Mediated Formation of Gas-Phase Amino Acid Radical Cations, J. Phys. Chem. A, 110 (2006) 8304-8315. [43] S. Osburn, R.A. O'Hair, V. Ryzhov, Gas-phase reactivity of sulfur-based radical ions of cysteine derivatives and small peptides, Int. J. Mass Spectrom., 316 (2012) 133-139.

[44] Q. Sun, S. Yin, J.A. Loo, R.R. Julian, Radical directed dissociation for facile identification of iodotyrosine residues using electrospray ionization mass spectrometry, Anal. Chem., 82 (2010) 3826-3833.

[45] T. Ly, R.R. Julian, Residue-specific radical-directed dissociation of whole proteins in the gas phase, J. Am. Chem. Soc., 130 (2008) 351-358. 
[46] T. Ly, R.R. Julian, Tracking radical migration in large hydrogen deficient peptides with covalent labels: facile movement does not equal indiscriminate fragmentation, J. Am. Soc. Mass Spectrom., 20 (2009) 1148-1158.

[47] C.-K. Siu, Y. Ke, Y. Guo, A.C. Hopkinson, K.M. Siu, Dissociations of copper (II)containing complexes of aromatic amino acids: radical cations of tryptophan, tyrosine, and phenylalanine, Phys. Chem. Chem. Phys., 10 (2008) 5908-5918.

[48] I.K. Chu, J. Zhao, M. Xu, S.O. Siu, A.C. Hopkinson, K.M. Siu, Are the radical centers in peptide radical cations mobile? The generation, tautomerism, and dissociation of isomeric $\alpha$ carbon-centered triglycine radical cations in the gas phase, J. Am. Chem. Soc., 130 (2008) 78627872 .

[49] A. Hopkinson, Radical cations of amino acids and peptides: structures and stabilities, Mass Spectrom. Rev., 28 (2009) 655-671.

[50] M. Xu, T. Song, Q. Quan, Q. Hao, D.-C. Fang, C.-K. Siu, I.K. Chu, Effect of the N-terminal basic residue on facile $\mathrm{C} \alpha-\mathrm{C}$ bond cleavages of aromatic-containing peptide radical cations, Phys. Chem. Chem. Phys., 13 (2011) 5888-5896.

[51] Y. Pyatkivskyy, V. Ryzhov, Coupling of ion-molecule reactions with liquid chromatography on a quadrupole ion trap mass spectrometer, Rapid Commun. Mass Spectrom., 22 (2008) 1288-1294.

[52] K.J. Miller, J. Savchik, A new empirical method to calculate average molecular polarizabilities, J. Am. Chem. Soc., 101 (1979) 7206-7213.

[53] T. Su, W.J. Chesnavich, Parametrization of the ion-polar molecule collision rate constant by trajectory calculations, J. Chem. Phys., 76 (1982) 5183-5185.

[54] M. Frisch, G. Trucks, H. Schlegel, G. Scuseria, M. Robb, J. Cheeseman, G. Scalmani, V. Barone, B. Mennucci, G. Petersson, Gaussian 09, revision A. 1, Gaussian Inc., Wallingford, CT, (2009).

[55] J. Howard, K.U. Ingold, The inhibited autoxidation of styren: Part IV. Solvent effects, Can. J. Chem., 42 (1964) 1044-1056.

[56] G. Litwinienko, K. Ingold, Solvent effects on the rates and mechanisms of reaction of phenols with free radicals, Acc. Chem. Res., 40 (2007) 222-230. 
[57] M.I. de Heer, P. Mulder, H.-G. Korth, K.U. Ingold, J. Lusztyk, Hydrogen atom abstraction kinetics from intramolecularly hydrogen bonded ubiquinol-0 and other (poly) methoxy phenols, J. Am. Chem. Soc., 122 (2000) 2355-2360.

[58] Y. Fu, Y. Mou, B.-L. Lin, L. Liu, Q.-X. Guo, Structures of the XY-NO molecules and homolytic dissociation energies of the Y-NO bonds ( $\mathrm{Y}=\mathrm{C}, \mathrm{N}, \mathrm{O}, \mathrm{S})$, J. Phys. Chem. A, 106 (2002) 12386-12392.

[59] R.P. Pesavento, W.A. Van Der Donk, Tyrosyl radical cofactors, Adv. Protein Chem., 58 (2001) 317-385.

[60] M. Högbom, M. Galander, M. Andersson, M. Kolberg, W. Hofbauer, G. Lassmann, P. Nordlund, F. Lendzian, Displacement of the tyrosyl radical cofactor in ribonucleotide reductase obtained by single-crystal high-field EPR and 1.4- $\AA$ x-ray data, Proc. Natl. Acad. Sci. U. S. A., 100 (2003) 3209-3214.

[61] C.W. Hoganson, C. Tommos, The function and characteristics of tyrosyl radical cofactors, Biochim. Biophys. Acta, Bioenerg., 1655 (2004) 116-122. 


\section{Supporting Information}

\section{The Effects of Intramolecular Hydrogen Bonding on the Reactivity of Phenoxyl Radicals in Model Systems}

Michael Lesslie, Andrii Piatkivskyi, John Lawler, Sandra Osburn, ${ }^{\dagger}$ Richard A. J. O’Hair, ${ }^{\dagger}$ and Victor Ryzhov*

Department of Chemistry and Biochemistry, and Center for Biochemical and Biophysical Sciences, Northern Illinois University, DeKalb, IL 60115, USA

$\dagger$ ARC Centre of Excellence for Free Radical Chemistry and Biotechnology, School of Chemistry and Bio21 Institute of Molecular Science and Biotechnology, The University of Melbourne, 30 Flemington Road, Parkville, Victoria 3010, Australia.

*Corresponding author, Email: ryzhov@ niu.edu 
Figure S1. CID of 4-methoxypyridine $(\mathrm{m} / \mathrm{z}, 110)$. The resulting ion at $\mathrm{m} / \mathrm{z} 95$ is the radical cation from homolytic cleavage of the $\mathrm{RO}-\mathrm{CH}_{3}$ bond, which corresponds to the radical cation of 4-hydroxypyridine.

Figure S2. Reactions enthalpies and free energies of radical combination between nitric oxide and the model compounds calculated at the 6-311++G(d,p) level of theory.

Figure S3. Calculated structures of the $\left[\operatorname{LysTyr}\left(\mathrm{O}^{\bullet}\right)\right]^{+}$radical cation in the gas phase. Structure A represents the lowest energy structure with a hydrogen bond to the phenoxyl radical of $1.7 \AA$. Structures B-D are higher energy structures lacking a hydrogen bond to the phenoxyl oxygen radical. Relative energies compared to structure $\mathbf{A}$ are given in $\mathrm{kcal} \mathrm{mol}^{-1}$. Calculations were performed at the $6-311++\mathrm{G}(\mathrm{d}, \mathrm{p})$ level of theory.

Figure S4. Spectra of the radical cation of the dipeptide LysTyr $(\mathrm{m} / \mathrm{z}, 309)$ is shown as isolated (a), reacting with nitric oxided (b) resulting in radical combination and the addition of $30 \mathrm{Da}$, and reacting with $n$-propyl thiol (c) resulting in HAT and the addition of 1 Da. Both reactions times were $5000 \mathrm{~ms}$.

Table S1. Calculated energies of the distonic and canonical forms of the radical cations of the model compounds: 4-hydroxypyridine, 2-hydroxypyridine, 8-hydroxyquinoline, and 2propyliminomethylphenol. Calculations were performed at the $6-311++\mathrm{G}(\mathrm{d}, \mathrm{p})$ level of theory. 


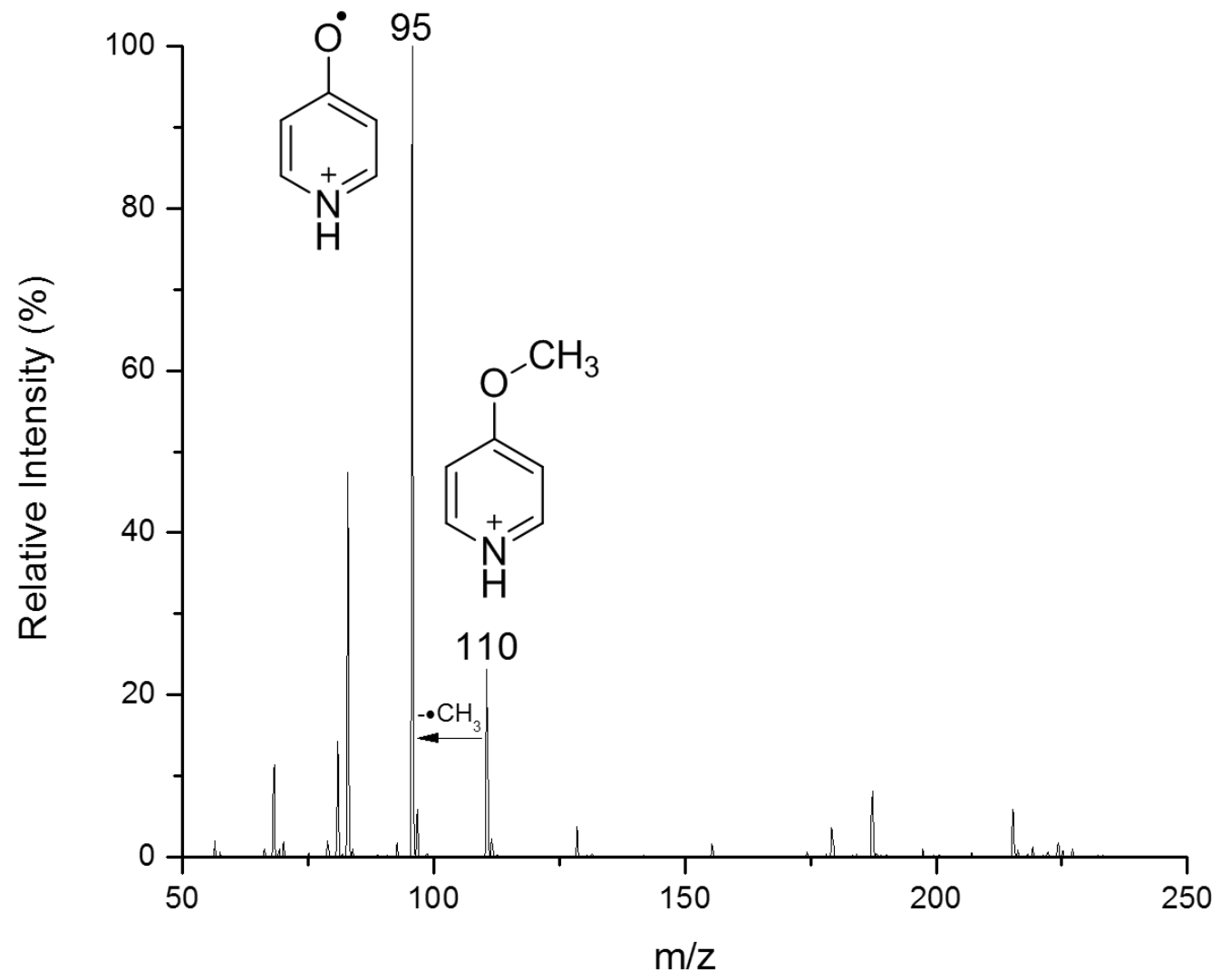

Figure S1 


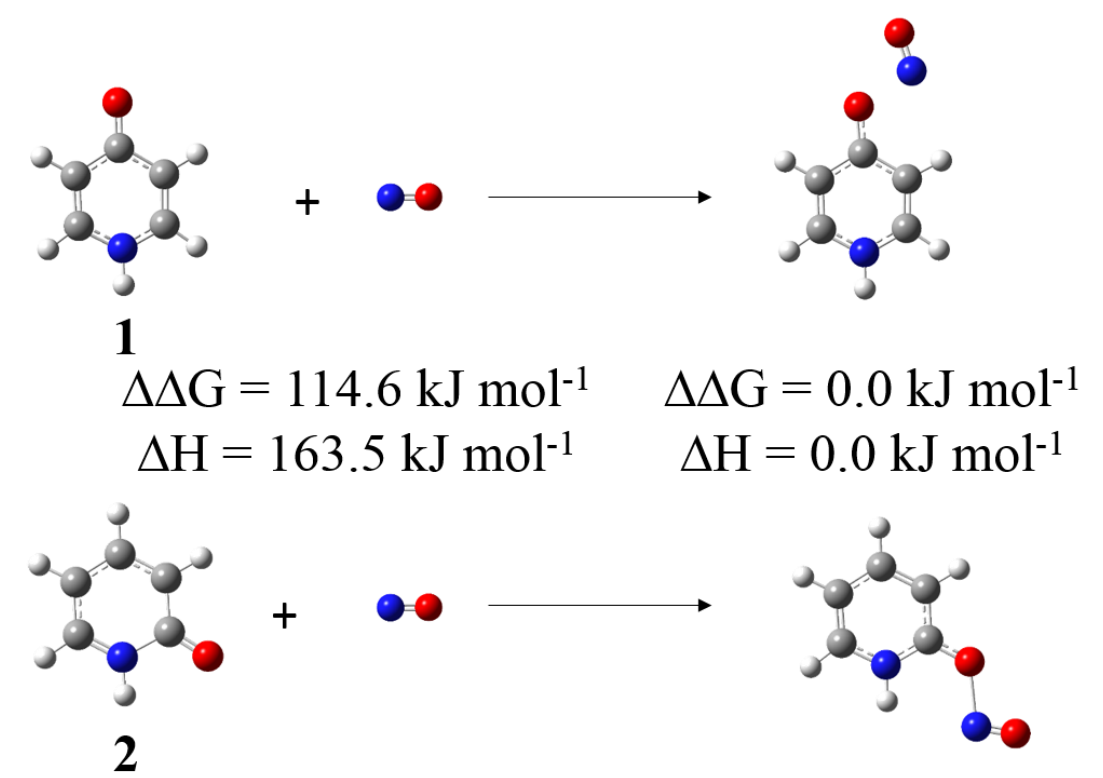

$$
\begin{aligned}
& \Delta \Delta \mathrm{G}=53.7 \mathrm{~kJ} \mathrm{~mol}^{-1} \quad \Delta \Delta \mathrm{G}=0.0 \mathrm{~kJ} \mathrm{~mol}^{-1} \\
& \Delta \mathrm{H}=102.7 \mathrm{~kJ} \mathrm{~mol}^{-1} \quad \Delta \mathrm{H}=0.0 \mathrm{~kJ} \mathrm{~mol}^{-1}
\end{aligned}
$$

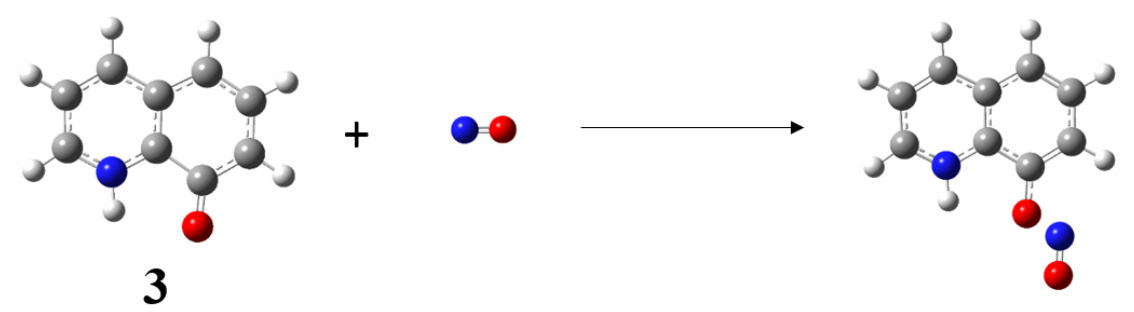

$$
\begin{array}{cc}
\Delta \Delta \mathrm{G}=19.9 \mathrm{~kJ} \mathrm{~mol}^{-1} & \Delta \Delta \mathrm{G}=0.0 \mathrm{~kJ} \mathrm{~mol}^{-1} \\
\Delta \mathrm{H}=64.4 \mathrm{~kJ} \mathrm{~mol}^{-1} & \Delta \mathrm{H}=0.0 \mathrm{~kJ} \mathrm{~mol}^{-1}
\end{array}
$$

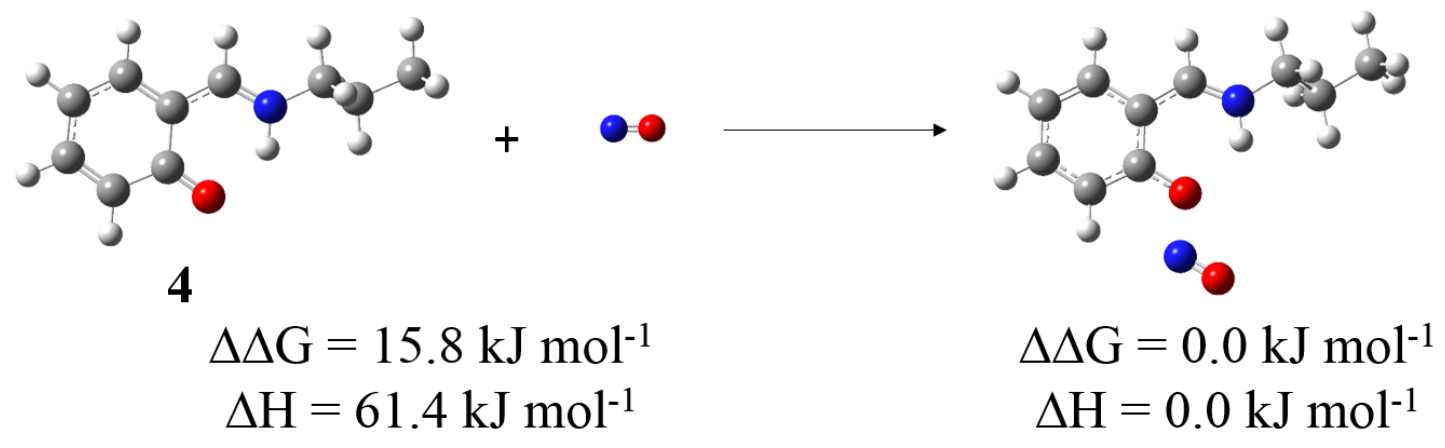

Figure S2 


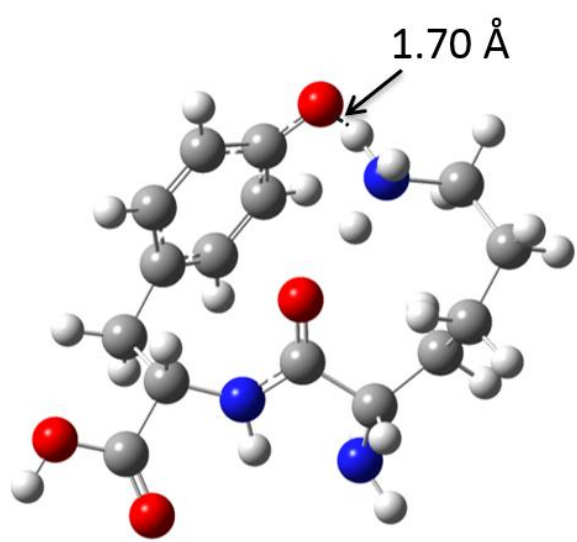

A

$0.0 \mathrm{~kJ} \mathrm{~mol}^{-1}$

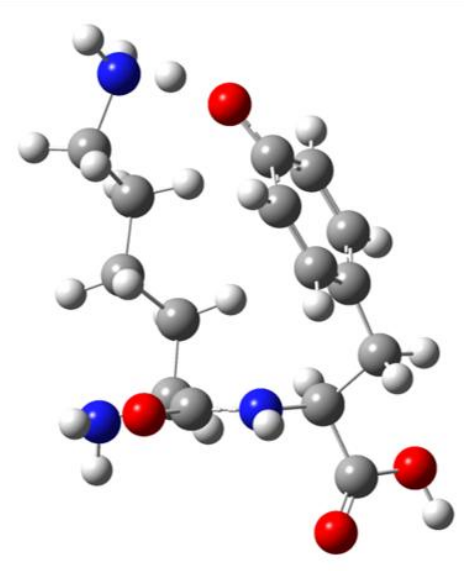

C

$105 \mathrm{~kJ} \mathrm{~mol}^{-1}$

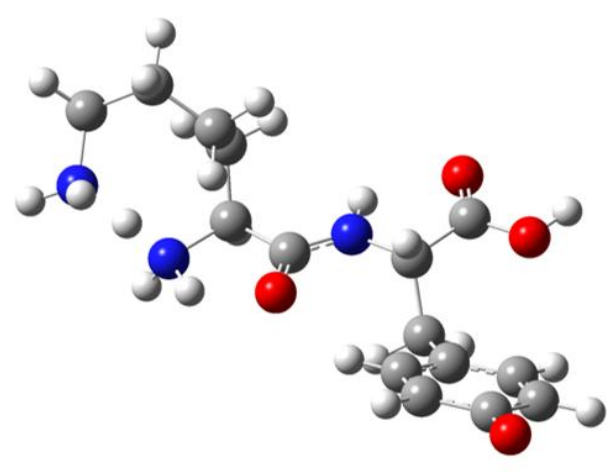

B

$41.84 \mathrm{~kJ} \mathrm{~mol}^{-1}$

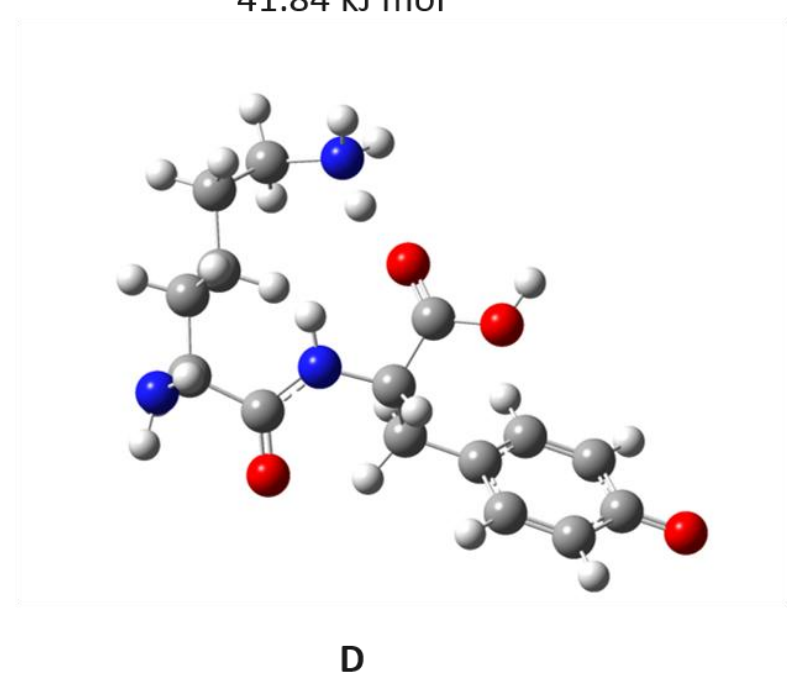

$159 \mathrm{~kJ} \mathrm{~mol}^{-1}$

Figure S3 
a)

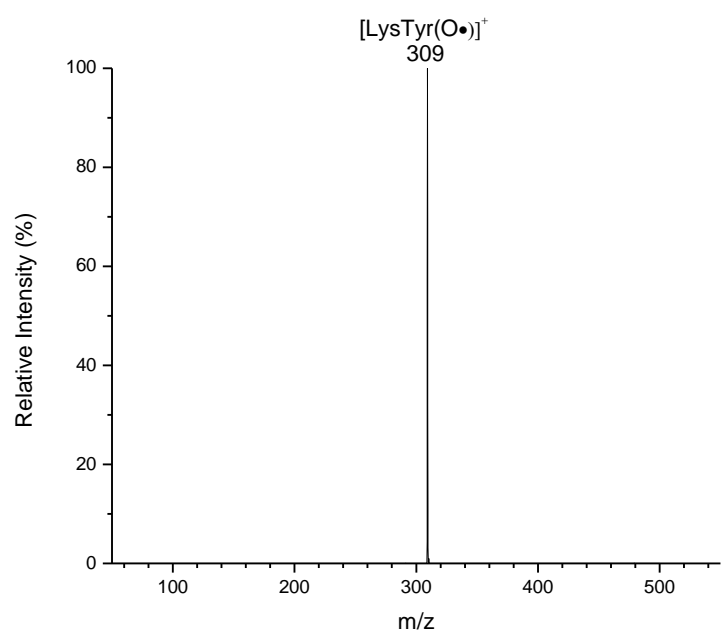

b)

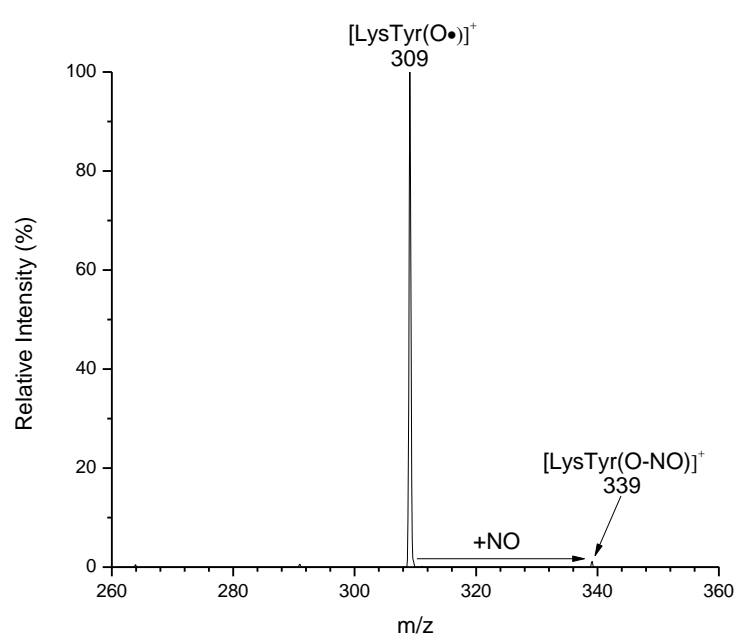

c)

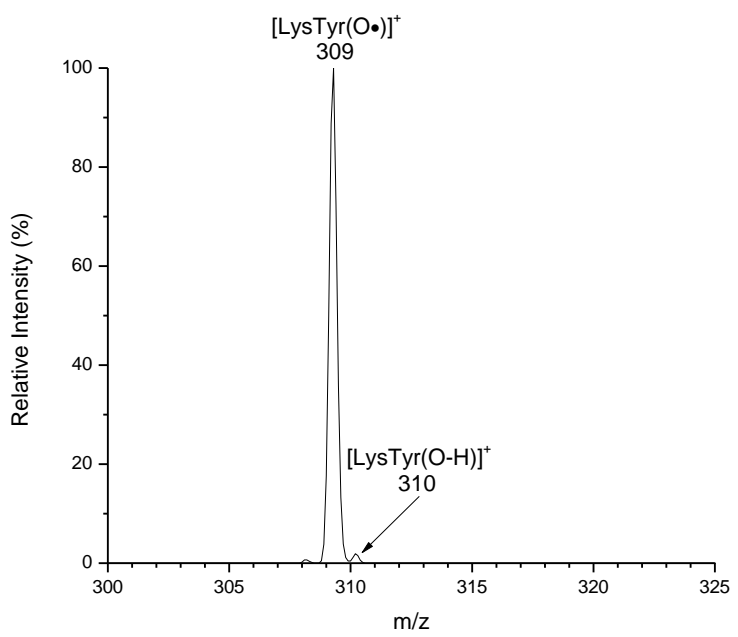

Figure S4 
Table S1

\begin{tabular}{|l|c|c|c|c|}
\hline & $\begin{array}{c}\mathbf{1} \\
\text { 4-Hydroxypyridine }\end{array}$ & $\begin{array}{c}\mathbf{2} \\
\text { 2-Hydroxypyridine }\end{array}$ & $\begin{array}{c}\mathbf{3} \\
\text { 8-Hydroxyquinoline }\end{array}$ & $\begin{array}{c}\mathbf{4} \\
\text { 2-Propyliminomethyl- } \\
\text { phenol }\end{array}$ \\
\hline $\begin{array}{l}\text { Distonic Radical } \\
\left(\mathrm{kJ} \mathrm{mol}^{-1}\right)\end{array}$ & 0.0 & 0.0 & 0.0 & 0.0 \\
\hline $\begin{array}{l}\text { Canonical Radical } \\
\left(\mathrm{kJ} \mathrm{mol}{ }^{-1}\right)\end{array}$ & 76.8 & 47.2 & 27.3 & $--*$ \\
\hline
\end{tabular}

*Radical species will not compute, calculation converges towards the distonic radical species. 


\section{University Library}

\section{- M I N E R VA}

\section{A gateway to Melbourne's research publications}

Minerva Access is the Institutional Repository of The University of Melbourne

\section{Author/s:}

Lesslie, M;Piatkivskyi, A;Lawler, J;Helgren, TR;Osburn, S;O'Hair, RAJ;Ryzhov, V

Title:

The effects of intramolecular hydrogen bonding on the reactivity of phenoxyl radicals in model systems

\section{Date:}

2015-11-15

\section{Citation:}

Lesslie, M., Piatkivskyi, A., Lawler, J., Helgren, T. R., Osburn, S., O'Hair, R. A. J. \& Ryzhov, V. (2015). The effects of intramolecular hydrogen bonding on the reactivity of phenoxyl radicals in model systems. INTERNATIONAL JOURNAL OF MASS SPECTROMETRY, 390, pp.124-131. https://doi.org/10.1016/j.ijms.2015.06.008.

Persistent Link:

http://hdl.handle.net/11343/57500 